\title{
Economic Consequences of Not Attending Business Classes
}

\author{
Michael Latta \\ Coastal Carolina University \\ Henry Lowenstein \\ Coastal Carolina University
}

\begin{abstract}
This paper presents three years of empirical research showing the most significant impediments to business major students' success is unexcused absences). This student misconduct results in squandered opportunities for learning, and squanders: 1) tuition paid by students and parents, 2) lost scholarships earned, 3) student loans acquired, and 4) state subsidies. To the extent this phenomenon magnifies across higher education, it contributes significantly to the national concerns about high tuition costs and the \$1.5 trillion student loan debt). By recognizing these economic factors university administrators can develop effective academic policies that ensure students attend classes. Some potential solutions are offered.
\end{abstract}

Keywords: economic, consequences, unexcused, absences, solutions

\section{INTRODUCTION}

In 1983, President Ronald Reagan issued a report that said America was at risk because American schools were not educating students: test scores were falling, millions of Americans were illiterate, and teachers weren't educated or paid enough to make a difference. Three recommendations were made: 1) more rigor was needed to better educate students, 2) standards needed to be raised for students to meet higher-level requirements to graduate, and 3) teacher training programs should require more of prospective teachers in terms of skills and abilities (Boyd, 2019).

Today, U.S. 15-year old students in both public and private schools participate in the Program for International Student Assessment (PISA). Results from the 2018 exam show no significant gains in math, reading, and science and U.S. students still can not compete with students from Asian countries (National Center for Educational Statistics Overview, 2019). Publication of the Programme for the International Assessment of Adult Competencies shows that U.S. Millennials lack skills in writing, reading, mathematics, and problem-solving in technology-rich environments (Stansbury, 2016). Despite having more education than previous generations, many graduate high school, complete college, find employment, and do not exhibit the skills needed to enter a competitive, global workforce that is technology-based.

In addition to this skills gap, much discussion has been made on the rising tuition and other costs of higher education (Fishman, 2015; Latif, E. \& Miles, S. 2013; Rahal, A., \& Zainuba, M. 2015; and U.S. Department of Education, National Center for Education Statistics, 2016). Some attention has been focused by the business press concerning return on investment for attending and graduating from college (Mitchell, Fuller, and Hackman, 2019; and Randazzo, S., 2019). The Wall Street Journal published one approach uses 
an interactive display to show differences between majors and universities illustrating which universities and majors lead to early pay back of the investment; and which leave graduates with large debt and little earning power (Mitchell, Fuller, and Hackman, 2019).

Concerns about class attendance involve a recognition by faculty that student attendance at classes taught by faculty are the heart of the higher education system. Research on attendance and achievement has included: attendance and achievement in microeconomic principles in classes taught at Salisbury University, Salisbury, MD resulting in a recommendation to encourage but not mandate attendance (Caviglie-Harris, 2006); to a meta-analytic analysis of 90 different samples totaling 28,034 students which showed a strong relationship between attendance and grades as well as failure rates (Crede, Roch, and Kieszczynka, 2010). That meta-analysis led the research team to conclude that attendance is a better predictor of grades than any other measures that have been used including SAT scores, high school GPA, study skills, and amount of time spent studying. It has been that way for over a millennium. No student learned from Socrates without attending his classes. The famed historian, Henry Adams remarked, "A teacher affects eternity; he can never tell where his influence stops (Adams, 1919)." Certainly, that influence is lost when a student decides to not participate in the learning process by not attending class.

This lost learning effect is independent of educational technology. The essential element of learning passed on by interaction with a live professor using online connection through Adobe Connect or other means is equally, if not more important. in the online environment as it is within the live classroom setting. Online assumptions of learning-equality with face-to-face classroom effectiveness may turn out to be unequal in mastering learning objectives and acquiring important skills.

Growing research concerning online learning reveals the modality, notwithstanding its alleged benefits, may nevertheless demand greater student-teacher interaction (plus high technology acquisition and maintenance costs), not less due to lack of physical classroom face-to-face presence.

"However, even if a virtual professor is competent enough to create a comfortable virtual environment in which the class can operate, still the lack of physical presence at an institution can be a limitation for an online program. For the faculty as well as the participants, such things as being left out of meetings and other events that require on-site interaction could present a limiting factor in an online program." (ILLINOIS ONLINE NETWORK, 2019).

Student decisions to absence themselves in an online environment is a recognized critical defect of distance learning as shown below.

"When students are left in charge of their own pace without any kind of pace monitoring by the stakeholders of the student (parent, facilitator, administration), there is a risk of students earning failing grades for work not attempted. Bright students, who are more than capable of doing the work, may let other things interfere. Procrastination is a killer in the online learning environment (Vangalis, 2019)."

Even though online sessions can be recorded and played back by online students later, these recordings do not allow for students to ask online faculty questions during the online session.

\section{ECONOMIC ISSUES RELATED TO ATTENDANCE}

In an era of great public concern about the costs of higher education, there appears to be little or no published research calculating: 1) wasted tuition paid by students and parents, 2) scholarships earned and lost, 3) student loans acquired, and 4) state subsidies incurred by a student not attending classes. In addition to lost learning and squandered financial resources, an accredited Business College may lose accreditation if graduating seniors do not show the skills included in the College assessment measurement system. 


\section{RESEARCH BACKGROUND}

Beginning in 2015, the authors began collecting data for the sections of the first author's Legal Environment of Business course to test the proposition that student unexcused absences were a major contributing factor to lower student academic achievement, leading ultimately to repeating the course.

Legal Environment of Business course is a core requirement in the B.S.B.A. degree program. It must be passed with a $\mathrm{C}(70 \%)$ or higher by all business majors. The course typically enrolls students with over 54 hours of university courses.

\section{INSTITUTIONAL POLICY}

The university, a new Strategic Plan for the university in 2016. A key element in the plan is Student Excellence. This component of the strategy is defined as:

"Promote an educational environment that engages students to develop knowledge, learn and apply skills, and act as responsible, healthy and productive citizens with a global perspective." (2016-2018 Strategic Plan.)

The 'responsibility' issue is the focus of this research.

The university has implemented a number of programs to support student learning, including: Tutoring, Writing Center, Testing Center, Library online-resources, and mentoring. A key missing element is requiring students to attend face-to-face classes is a challenge, but none the less of key importance to the educational mission.

The curriculum at this and other universities is established by faculty, many of whom are experienced in their content specialty and know the University, College and AACSB standards. These faculty are in charge of what subjects and skills are necessary and essential to student success in their respective fields. Students lack essential knowledge of a field of study (major) and are not in a position to judge what is or is not essential to learning. Every major and degree has courses students do not like or find too difficult, and would on their own never take. Nevertheless, core courses in each discipline reflect academic needs.

Consider the academic implications if students who do not like numbers evade attending quantitative courses such as mathematics, statistics, accounting, economics, and marketing research. These courses are all critically important subjects that underlies a BSBA degree major. Students who do not read, write, or critically evaluate issues, evade written and oral communication-related courses such as business law with its heavy reading/writing assessments.

This study is designed to show the effects of skipping classes on learning as well as economic outcomes such as squandered tuition and state subsidies.

\section{METHOD}

An earlier research study of the Marketing Major Capstone course in the College of Business (Latta and Lowenstein, 2017) demonstrated that the more students attended classes, the better their grades were and the less tuition dollars were squandered. The current research involves a BSBA required course Legal Environment of Business that all business students must pass with a $\mathrm{C}$ or better to continue in the undergraduate program.

For Spring Semester 2018 and 2019, three sections of Legal Environment of Business were taught faceto-face by the leading professor. Each class met twice a week (Tuesdays and Thursdays). Because it is a required business core course; learning is intense and comprehensive.

Section enrollment in 2018 was 33, 34 and 35 respectively for a total enrollment of 102 students. Enrollment in 2019 was 31, 30, 32 for a total of 93 students. This sample of 195 students represents 5\% of the total enrollment of the College of Business. The sample classes represented all majors in the College with students from over 28 states and 3 foreign nations. In addition, 9.9\% of the class were from majors 
outside the College of Business. Attendance was taken in each class period for each section. If a student attended all or all but 1 of the class periods, the student was classified as Attending. All other students were classified as Unexcused.

Students received ALL class participation points the first day of class and lost points for each unexcused absence. This approach makes logical sense as a student not present by definition is not participating. Beginning Academic Year 2017-18, the course specifically includes the University's newly enacted Class Attendance Policy (2016). The policy enumerates a narrow list of excused absences and expects students will attend every class session. The data are summarized as the average grade scores of a class section classified as being in either the Attending or Unexcused absences category based on class attendance.

\section{RESULTS}

\section{Squandered Opportunities for Learning}

The sample frame for this research is in Table 1 below. Among the six class sections, unexcused absences range from one week to as high as two weeks of missed instruction.

TABLE 1

SAMPLE FRAME

\begin{tabular}{|c|c|c|c|c|}
\hline Section & Class Size & $\begin{array}{c}\text { Number of } \\
\text { Unexcused } \\
\text { Students }\end{array}$ & $\begin{array}{c}\text { Number of } \\
\text { Unexcused } \\
\text { Absences }\end{array}$ & $\begin{array}{c}\text { Class } \\
\text { Average Number of } \\
\text { Missed Classes }\end{array}$ \\
\hline $2018 \quad 02$ & 33 & 15 & 64 & 1.94 \\
\hline $2019 \quad 02$ & 31 & 20 & 139 & 4.48 \\
\hline $2018 \quad 03$ & 34 & 22 & 93 & 2.74 \\
\hline $2019 \quad 03$ & 30 & 13 & 48 & 1.60 \\
\hline $2018 \quad 05$ & 35 & 20 & 76 & 2.17 \\
\hline 201905 & 32 & 17 & 110 & 3.44 \\
\hline TOTAL & 195 & 57 & 530 & 2.72 \\
\hline
\end{tabular}

The amount of squandered opportunity for learning appears in Table 2 below which shows the effects of not attending classes on student learning reflected in final course grades.

TABLE 2

FINL GRADE SCORES FOR ATTENDING VS. UNEXCUSED STUDENTS

\begin{tabular}{|c|c|c|c|c|}
\hline Section & Class Size & Attending & Unexcused & Total \\
\hline $2018 \quad 02$ & 33 & $82.1 \%$ & $66.1 \%$ & $77 \%$ \\
\hline 201902 & 31 & $75.9 \%$ & $65.2 \%$ & $74 \%$ \\
\hline 201803 & 34 & $82.8 \%$ & $70.2 \%$ & $76 \%$ \\
\hline 201903 & 30 & $83.3 \%$ & $76.4 \%$ & $81 \%$ \\
\hline 201805 & 35 & $82.1 \%$ & $71.6 \%$ & $78 \%$ \\
\hline 201905 & 32 & $78.0 \%$ & $69.5 \%$ & $76 \%$ \\
\hline TOTAL & 195 & $80.7 \%$ & $69.8 \%$ & $77 \%$ \\
\hline
\end{tabular}

As can be seen in Table 2, Attending students score a B+ final grade overall compared to a $\mathrm{C}$ overall for students with Unexcused Absences. While a $\mathrm{C}$ is satisfactory as a minimum grade for the BSBA degree, it does not exhibit excellence. On average, students with Unexcused Absences are skipping nearly three (3) weeks of learning out of a 15 week semester or $20 \%$ of total instruction. 


\section{Squandered Tuition and Public Subsidy}

Not only is there Squandered Opportunity for Learning, there is also the issue of Squandered Tuition and lost Public Subsidy.

Table 3 below shows the estimated Squandered Tuition and Public Subsidy of students not attending class. Squandered Tuition can be estimated using an average of out-of-state and in-state tuition not counting room, board and other fees. This calculation indicates an economic impact of not attending class of $\$ 435$ per class session on a twice a week semester basis. To be complete in this estimate, another 5\% must be added to cover the percentage of subsidy from the State to the university. This $5 \%$ represents the public money value lost by the student not attending class.

The six classes together showed a total Squandered Tuition and State Subsidy of nearly $\$ 242,078$ or $\$ 40,346$ per class section; the equivalent of nearly three full time in-state student tuitions and fees. The public subsidy squandered $\$ 11,538$ is a direct misallocation of public taxpayer funds by student behavior; nearly the full tuition and fees for one in-state student, not to mention the value of lost learning.

TABLE 3

\section{SQUANDERED TUITION AND STATE SUBSIDY FROM UNEXCUSED ABSENCES}

\begin{tabular}{|c|c|c|c|c|c|}
\hline Section & $\begin{array}{l}\text { Class } \\
\text { Size }\end{array}$ & $\begin{array}{c}\text { Number of } \\
\text { Unexcused } \\
\text { Absences } \\
\end{array}$ & $\begin{array}{c}\text { Squandered } \\
\text { Tuition }\end{array}$ & $\begin{array}{l}\text { Public } \\
\text { Subsidy }\end{array}$ & $\begin{array}{c}\text { Total Costs } \\
\text { SQUANDERED }\end{array}$ \\
\hline $2018 \quad 02$ & 33 & 64 & $\$ 27,840$ & $\$ 1,392$ & $\$ 29,098$ \\
\hline 201902 & 31 & 139 & $\$ 60,465$ & $\$ 3.023$ & $\$ 63,488$ \\
\hline $2018 \quad 03$ & 34 & 93 & $\$ 40,269$ & $\$ 2,014$ & $\$ 42,283$ \\
\hline 201903 & 30 & 48 & $\$ 20,880$ & $\$ 1,044$ & $\$ 21,924$ \\
\hline $2018 \quad 05$ & 35 & 76 & $\$ 33,060$ & $\$ 1,653$ & $\$ 34,713$ \\
\hline $2019 \quad 05$ & 32 & 110 & $\$ 47,850$ & $\$ 2,393$ & $\$ 34,553$ \\
\hline TOTAL & 195 & 530 & $\$ 230,550$ & $\$ 11,538$ & $\$ 242,078$ \\
\hline
\end{tabular}

\section{DISCUSSION}

The economic loss in this analysis is similar to a person purchasing a theater, concert, or football ticket and does not show up for the event. The event takes place, it is missed and the money spent is nonrefundable. To the extent this loss is repeated thousands, even millions of times across the nation, it defines a massive amount of wasted tuition and state subsidy dollars approaching $\$ 1.5$ trillion in U.S. student loan debt.

\section{Potential Solutions}

Some potential solutions require supporting university wide policies and others can be implemented by individual faculty without consideration of university policies.

1. Attendance Notification to Tuition Payers: Recognizing that students do not behave responsibly, the most effective partner to universities in assuring learning is accountability to the tuition payer. Establishing a means of alerting those who pay the bill to student absences of 2 or more would reduce the problem, before material damage to the student's grade. The Tuition Payer may be the student themselves, parents, scholarship payers, government agencies. (Ironically, some single parent students on state assistance are required to produce an attendance sheet each month to the agency of record to continue funding.)

Institutions frequently claim an inability to engage in such notification process due to restrictions under the federal Family Education Rights and Privacy Act (FERPA). Yet, there are ways within FERPA to achieve results and for those not covered. FERPA allows for such notices where a student is declared as a dependent on the parents federal income tax return (IRS 
1040 Income Tax form). An innovative university could apply to the U.S. Dept. of Education for a demonstration project waiver to implement and demonstrate the positive learning effect, pre- and post-test of a tuition payer notification system related to attendance.

In addition, a link on the university registration system (Banner, Datatel, PeopleSoft among others) would allow faculty to be alerted when any student exceeds 1 or more unexcused absences. The system would then send an automatic email notice to the appropriate third-party payer. A parent or guardian, especially out-of-state-paying $\$ 30,000$ a year or more tuition would probably want to correct their son or daughter's poor class attendance and would be in the best position to do so!

2. Make Attendance a Requirement of Financial Assistance: University financial assistance is limited with more students needing financial aid than funds available. If a student is receiving financial aid be it scholarships, fellowships, grants or student loans and does not show up for classes, the aid should be pulled and given to another deserving student who does value their education. This approach should also have an early warning system when skipping classes occurs. Such a system is already in place in some state grant-in-aid programs but not all financial aid programs and systems.

3. Implement a Priority Registration System Based on Attendance Records: With tight university budgets class seats for high demand courses in majors is at a premium in many institutions. When a student takes up a seat and does not attend class (many times dropping later in the semester) that student deprives a serious student of a needed course seat to complete a degree program. In such circumstances, students with good attendance records getting priority registration not only ensures better retention, but acts as a key incentive for students to avoid unexcused absences because of the real consequence to getting the courses at the times, and with the professor they prefer. This system also helps keep time to completion of degree on track

4. Create and Enforce a University Wide Class Attendance Policy- The authors' University for example, has a written attendance policy stating when a student reaches $25 \%$ unexcused absences the professor may give a failing grade. The term "may" allows the faculty member to mandate it in a syllabus. This approach applies to unexcused absences only. In a twice a week 15 week semester with 30 class sessions, when 8 class sessions are skipped [equaling 4 weeks of missed course work] the student can automatically receive a failing grade for the course. The "may" could change to "must" except in truly extenuating circumstances if a stronger policy is implemented.

5. Develop Policies to Discourage Student Extension of University Breaks and Holidays An adverse student behavior well known to faculty and administrators is student piggy-backing unexcused absences on university holidays to expand official breaks. For example, on Spring Break students will skip the Thursday or Friday class before the break and the Monday or Tuesday class afterwards to effectively stretch a one week, into a two-week holiday. However, the two unexcused absences (on twice a week course) means an entire week of lost learning. Likewise, Friday "Student Holidays" find students missing either the Thursday before and possibly the Monday after to stretch the holiday from a 3 day to a 5 day break. Often, in Spring Semester, students lose even more days when their last minute "late" return encounters inevitable late winter weather delays or transportation cancellations in return travel. Those students then protest and pressure faculty to "excuse" their skipping class. Some faculty attempt to mitigate the problem by scheduling a test before or after a break. Policies should be considered and enforced that help prevent these unexcused absence behaviors.

\section{CONCLUSION}

Research on attendance indicates: high class attendance leads to high academic performance in first year accounting students in South African University (Papageorgiou and Townsend, 2014); that having an 
explicit attendance policy reduces absenteeism in a Principles of Macro-Economics course at a Missouri State University (Self, 2012); higher pass rates occur in a Calculus course required for a bachelors' degree program of Life Science and Technology at Delft University of Technology in the Netherlands over several years (Meulenbroek and van den Bogaard, 2013); and in a quasi-experimental study of managerial communication students at Central Connecticut State University (Snyder and Frank, 2016).

The potential solutions are not offered to be punitive but to ensure students are focused on learning and not squandering tuition paid regardless of the funding source. It is clearly in the students' best interests to be in class. Employers prefer graduates who are reliable and show up for work reliably.

Many employers including the authors' university's policy for its own employees prohibits employees from having, "Habitual Tardiness or Failure to Observe Assigned Work Hours," and, "Unauthorized Leaves;" all of which may lead to termination of employment. A university that would no more tolerate unexcused absences of its own employees, should likewise not allow unexcused student absences to undermine its core mission of educating students.

If faculty and administrators can convince students that education and career success arises from reliable attendance, it will reduce squandered tuition paid by students and parents, prevent loss of scholarships earned, encourage pay back of student loans acquired, 4) prevent state subsidies being squandered, and may increase retention. This change could eventually lead to improved economic development of or communities, and prosperity in the nation.

Perhaps the famous actor and movie director, Woody Allen was correct in his 1977 United Artists movie Annie Hall when he said: "80 percent of success is showing up!"

\section{REFERENCES}

AACSB International (n.d.). 2013 Business Accreditation Standards. Standard, 8. Retrieved June 18, 2019, from http://www.aacsb.edu/en/accreditation/standards/2013-business/learning-andteaching/standard8/

Adams, H. (1919). The Education of Henry Adams. Originally Self-Published, available in Project Gutenberg, 2044, Champaign Ill.

Boyd, N. (2019). A Nation at Risk. Retrieved November 29, 2019, from https://study.com/academy/lesson/a-nation-at-risk-summary-effects-oneducation.html\#/transcriptHeader

Caviglia-Harris, J. (2006, Winter). Attendance and Achievement in Economics: Investigating the Impact of Attendance Policies and Absentee Rates on Student Performance. Journal of Economics and Finance Education, 4(2), 1-15.

Class Attendance Policy. (2016, April). Coastal Carolina University Policies and Procedures. $A C A D$ SENA, 129.

Fishman, C. (2015, January 5). The price tag on skipping class. Paste Magazine. Retrieved November 29, 2019, from http://www.pastemagazine.com/articles/2015/01/the-price-tag-on-skipping-class.html

Latif, E., \& Miles, S. (2013, December). Class Attendance and Academic Performance: A Panel Data Analysis. Economic Papers, 32(4), 470-476.

Latta, M., \& Lowenstein, H. (2017). Lost Learning and Squandered Tuition: Economic Consequences of not Attending Class in Undergraduate Business Courses. Journal of Higher Education Theory and Practice, 17(1), 74-80.

Lowenstein, H. (2016, Winter). The Great Wall of FERPA: Surmounting a Law's Barrier to Assurance of Learning. Journal of Legal Studies Education, 33(1), 129-164.

Mitchell, J., Fuller, A., \& Hackman, M. (2019, November 28). Which College Graduates Make the Most? The Wall Street Journal. Retrieved November 29, 2019, from https://www.wsj.com/articles/which-college-graduates-make-the-most11574267424? emailToken=167db583a1369776030d56a0c8ebbe639GtCCDgdAiqYP4ccehbPm0 71KMCUIXsZ7knUNiGh7avp4RcIKJD/KFIXTwByhkq5btBtuw4e4ScFEtSXIA5REz0hWILHP NbcalClBZcLTKQ\%3D\&reflink=article_email_share 
Meulenbrock, B., \& Bogaard, M.V.D. (2013). Attendance and Attainment in a Calculus Course. European Journal of Engineering Education, 38(5), 532-542.

Papageorgiou, E., \& Townsend, P. (2014). Does Lecture Attendance Matter? The Good, Bad and The Ugly. South African Journal Higher Education, 28(5), 1625-1642.

Program for International Student Assessment Overview. (n.d.). Received December 26, 2019, from https://nces.ed.gov/surveys/pisa/

Rahal, A., \& Zainuba, M. (2015). Improving Students' Performance in Quantitative Courses: The Case of Academic Motivation and Predictive Analytics. The International Journal of Management Education, 14, 8-17.

Randazzo, S. (2019, November 27). New Lawyers are Swimming in Debt. The Wall Street Journal. Retrieved November 29, 2019, from https://www.wsj.com/articles/new-lawyers-are-swimmingin-debt-11574890294

Self, S. (2012). Studying Absenteeism in Principles of Macroeconomics: Do Attendance Policies Make a Difference? Research in Economic Education, 43(3), 223-234.

Snyder, J., \& Frank, L. (2016). Attendance Policies, Instructor, Communication, Student Attendance, and Learning. Journal of Education for Business, 91(2), 108-116.

Stansbury, M. (2016, March 18). Shocking data reveals Millennials lacking skills across board. Retrieved November 29, 2019, from https://www.ecampusnews.com/2016/03/18/millennials-skills-piaac$388 /$

Strengths and Weaknesses of Online Learning. (2019). ILLINOIS ONLINE NETWORK. Retrieved June 18, 2019, from https://www.uis.edu/ion/resources/tutorials/online-education-overview/strengthsand-weaknesses/

2016-2018 Strategic Plan. (n.d.). Coastal Carolina University. Retrieved June 18, 2019, from www.coastal.edu.

U.S. Department of Education, National Center for Education Statistics. (2016). The Condition of Education 2016 (NCES 2016-144), Undergraduate Retention and Graduation Rates. Retrieved November 29, 2019, from http://vassarstats.net/rdiff.html

Vangalis, M. (2019). Strengths and Weaknesses of Online Learning. The Virtual Voice-Florida Virtual School Blog. Retrieved June 18, 2019, from https://blog.flvs.net/strengths-and-weaknesses-ofonline-learning/ 